\title{
INTEREST OF SHARING AND INTEREST OF ACCESSING ACCOUNTING KNOWLEDGE VIA YOUTUBE
}

\author{
$1^{\text {st }}$ Charles Tang \\ Business Management \\ Politeknik Negeri Batam \\ Batam, Indonesia \\ tongmingkuang.ct@gmail.com \\ $2^{\text {nd }}$ Christina \\ Business management \\ Politeknik Negeri Batam \\ Batam, Indonesia \\ christinachen.kibb1@gmail.com
}

\author{
$3^{\text {rd }}$ July Artika \\ Business management \\ Politeknik Negeri Batam \\ Batam, Indonesia \\ juliartika16@gmail.com \\ $4^{\text {th }}$ Danar Irianto, S.E., M.Acc., AK \\ Business management \\ Politeknik Negeri Batam \\ Batam, Indonesia \\ danar@polibatam.ac.id
}

\begin{abstract}
Technological development is a challenge for Indonesia to facing 4.0 industry revolutions. Teaching methods in higher education need to be developed to produce quality college students. YouTube videos can be a solution for college students in teaching and learning activities. This study purposes to determine college student interest in sharing and accessing accounting knowledge through YouTube. Qualitative descriptive approaches and case studies were used in this study. The object of the research was Batam State Polytechnic college students majoring in Business Management, semester 2, 4 and 6 Accounting study programs. The technique of determining the number of samples uses the Gay \& Diehl Theory. Purposive sampling is used as a sampling technique. Data collection is indepth interviews and documentation. Data analysis techniques use interactive data analysis techniques. The results of the study indicate that college students are quite interested in sharing and accessing accounting knowledge through YouTube. College students realize that there are many benefits that can be obtained through YouTube, but college students cannot use it properly. The things that were a problem were the lack of knowledge about making videos and the limitations of internet networks.
\end{abstract}

Keywords: YouTube, interest in sharing; interest in accessing; accounting learning

\section{INTRODUCTION}

YouTube is a well-known application by people from all around the world. Not only young people who access this application, from youth to the elderly use the YouTube application. Various kinds of needs and desires can be accessed through video content provided by YouTube media. YouTuber has become an interesting profession nowadays. Youtuber can earn money by creating and uploading interesting and creative videos make this proffesion interesting. Some successful YouTubers even leave their previous professions and pursue the YouTuber profession. Some artists also participate in the YouTuber profession.

Indonesia also has a plenty of potential YouTubers. Two of successful Indonesian YouTuber who was crowned King and Queen of YouTuber of the country by social media netizens. They are Atta Halilintar and Ria Ricis. These two figures became the first of two people who successfully obtain the Diamond Play Button in Southeast Asia. This
Diamond Play Button is an award given to YouTubers who managed to penetrate 10 million subscribers. This achievement is certainly a pride.

YouTube application is the most popular application in Indonesia. The results of the Google and Kantar TNS survey in January 2018 revealed that the number of YouTube application users in Indonesia reached 53\% of all internet users in Indonesia. This shows that YouTube application is a very popular media in Indonesia.

The urge of accessing and uploading videos on YouTube is dominated by various kinds of motivation. Not just a simple entertainment, interest in finding new information and also learning something is a part of some users motivation to access videos on YouTube. According to Almobarraz (2018) more than half of users only access YouTube videos and do not contribute to creating and uploading video content.

Technology advancement is a challenge for Indonesia in facing the 4.0 revolution era. Teaching methods in higher education need to be developed to produce quality college students to face the 4.0 revolution. Teaching and learning activities in the classroom conventionally turn to digital content. The material delivered by the lecturer cannot be absorbed entirely by college students. YouTube videos can be a solution to access lecture material wherever and whenever as needed.

The author has an accounting background, so the author wants to do research related to the interest of college students to share and access accounting knowledge through YouTube. The author uses YouTube as a learning media because YouTube is very easy to access and very much in demand.

Based on the background described previously, there are two formulations of the problems to be raised in this study. First, are college students interested in sharing accounting knowledge through Youtube? Second, are college students interested in accessing accounting knowledge through Youtube?

Based on the problem formulation, there are two research objectives. First is to find out the interest of college students in sharing accounting knowledge through YouTube. Second 
is to find out the interest of college students in accessing accounting knowledge through YouTube.

In accordance with the results of previous studies, social media can be used in universities or college. YouTube is more often accessed via computer when learning in the class, whereas other social media are accessed more via smartphones (Nurkhin \& Fachrurrozie, 2018). According to Almobarraz (2018), YouTube can be used by college students in universities. The subjects of the most sought-after video clips are video clips related to education with the highest percentage of $48.3 \%$.

\section{LITERATURE REVIEW}

Technology Determinism Theory is a theory that explains the changes that have taken place in the development of technology since ancient times up to now have a great influence on society. This theory states that the relationship between society and technology is a relationship that affects each other, so that the existence and development of technology also determines the development and changes in social values and life in society. Marshall McLuhan has a view of technology as an extension of humans and their needs. Technology that has been made so far aims to facilitate all human activities and extension of our five senses (McLuhan, 1962).

Social Learning Theory is a theory that assumes everyone learns through direct experience or observation and then imitates the model. It can also be from what he reads, hears and sees on the media, as well as from people in the environment. Bandura's theory describes human behavior as a continuous reciprocal interaction between environment, cognitive and behavior. Cognitive is influenced by several factors, namely knowledge, expectations and attitudes of each individual. The environmental conditions that exist around individuals affect this type of social learning pattern. Learning theory is also developed to explain how a person learns in an actual situation or environment (Bandura, 1977).

Behavior Theory is a theory that states behavior changes as a result of experience. Then this theory developed into the flow of learning psychology that has an influence on the development of education and learning theory known as behavioristic flow. Behaviorism does not question whether humans are good or bad, rational or emotional, behaviorism only wants to know how behavior is controlled by environmental factors. In other words, learning theory places more emphasis on human behavior (Berliner \& Gage, 1984).

According to the A Statement of Basic Accounting Theory (ASOBAT), accounting is the process of defining, measuring and delivering economic information as information material in terms of considering various alternatives in decision making (Syakur, 2015). Meanwhile, according to the American Institute of Certified Public Accounting (AICPA), accounting as an art of recording, classifying and summarizing in a certain way and in monetary terms, transactions and events that are generally financial in nature and include interpreting the results (Syakur, 2015).

Based on Law Number 20 of 2003 concerning the National Education System, "Learning is the process of interaction of college students with education and learning resources in a learning environment." It was concluded that accounting learning is the process of interaction of college students with education and accounting learning resources in a learning environment to obtain accounting skills.

The theory of Uses and Gratifications is a theory which states that media users play an active role in selecting and using the media. Technology and information that develops very quickly makes people faced with many choices, needs and willingness. College students make social media as a means to obtain information, means of interaction and communication, and other aspects. With social media, college students can learn without limits of space and time and are more effective and efficient. This is in line with the uses and gratifications approach which views that media selection can give satisfaction to everyone in meeting their needs and everyone can understand various reasons for using media (Blumer \& Katz, 1974).

Learning media is very important in the teaching and learning process. Learning media is a messenger technology that can be used for learning purposes (Schramm, 1977). Whereas According to (Briggs, 1977), learning media are physical means to convey learning content / material such as books, films, videos, slides and so on.

Information technology has an important role in the current millennial era, including in the education sector. The important activity of the education sector is the teaching and learning process. Social media that can be used in learning is YouTube. YouTube users can load, watch and share video clips for free. There are various kinds of video clips uploaded by various groups of users, ranging from tutorials, music clips, educational videos, short films, television movies, video blogs and so on.

Nurkhin \& Fachrurrozie (2018) have examined the use of social media for accounting learning in higher education. Empirical studies at Semarang State University show that learning through social media can be utilized. This can be seen in the results of the acquisition score showing 4.33. Respondents' answers use a scale of 1-5. YouTube is a social media that is often used in accounting learning with the highest score of 4.22. Meanwhile Twitter is a social media platform that is almost never used for learning with a score of only 2.22. The score obtained for the use of Facebook is 3.67 and Instagram at 2.67. YouTube is more often accessed via a computer when learning in class, whereas other social media are accessed more via smartphones.

Almobarraz (2018) examines the use of YouTube as a source of information to support university programs at $\mathrm{Al}$ Imam Mohammad Ibn Saud Islamic University (IMSIU), Saudi Arabia. The results of the study show that YouTube can be used by college students in universities. This seems from the highest percentage of $32.6 \%$ of college students tend to watch YouTube videos more than 13 times a week, while the lowest percentage of 5.6\% watch YouTube videos once a week. The subjects of the video clips were most sought by college students among all participants, the highest number of $48.3 \%$ reporting that they were most often looking for educational video-related clips, followed by 
video clips related to entertainment $29.2 \%$, culture $16.9 \%$, $2.3 \%$ news and other videos $3.3 \%$.

\section{RESEARCH METHOD}

This research use desciptive qualitative approach. Qualitative descriptive research is intended to describe existing phenomena (Sukmadinata, 2011). In accordance with the current phenomenon, namely the development of industrial era 4.0, education must also undergo a revolution. The purpose of this study is trying to know the problems and provide solutions in the form of facts relating to the current status of the subject under study.

The study uses case studies method because researchers want to explore information relating to current conditions regarding the interests of college students. The information obtained helps researchers get solutions on how to implement learning through YouTube intensively. Based on the problems found by researchers, researchers will look for facts related to the phenomenon of research. The results of case studies are useful in understanding the phenomena that occur.

The objects of this study were Batam State Polytechnic College students majoring in Business Management, semester 2, 4 and 6 Accounting study programs. Determination of the number of informants followed the theory of Gay \& Diehl (1992). The assumptions conveyed are based on the greater the informants taken, the more representative. However, the exact size of the informant to be taken depends on the type of research being worked on. This study uses a descriptive approach, so the number of informants used is $10 \%$ of the collection of informants.

The researcher took 17 people from a total of 170 informants. The purposive informant retrieval technique was used in selecting college students who were used as informants for research. Purposive techniques take informants based on certain considerations (Notoatmodjo, 2010). The researcher uses this technique so that the informant is expected to be able to describe the characteristics of the whole informant. The characteristics of the informants were college students with the highest, middle and lowest GPA in the class.

Qualitative research has the characteristics of interpretation research, in which the researcher is involved in the experience of the phenomenon at hand. The research instrument used by researchers was in the form of interview guidelines by conducting face to face interviews (personal interviews) with college students. The researcher asked a number of questions related to college student responses to interest in sharing and accessing accounting knowledge through YouTube.

Data recording uses semi-structured interview guidelines (Interview guide or interview schedule). Questioned interview questions in the form of general and open questions are designed to bring out the views and opinions of college students. The researcher used a cellphone recorder to record sound and a cellphone camera to document the interview process, and then recorded important points related to the interview.
This research was conducted at Batam State Polytechnic. Batam State Polytechnic is the only State University in the city of Batam and in the province of Riau Islands. The College is located on Jl. Ahmad Yani, Tlk. Tering, Batam Kota Regency, Batam City, Riau Islands.

Data collection carried out in this study used the technique of in-depth interviews and documentation. The interview process is carried out by asking research questions. The results of the interview are in the form of data about the opinions and ideas of the respondents based on the problems raised. Documentation is used as a supporter that strengthens the data obtained through interviews.

There are three research variables used in this research. First, is college student Interest in Sharing Accounting Knowledge. Interest means feeling interested in something or activity, (Djaali, 2007). The interest of college students in sharing knowledge from accounting materials caused by various of external and internal factors. Impact of sharing their knowledge, college students are expected to enrich or publish their own insights about what they have presented. Second, is college student Interest in Accessing Accounting Knowlegde. This interest can help college students find information they are needed. Students can also review the Accounting material everytime they want to. Accessible information able to add student's understanding and knowledge. Third, YouTube Media Use. YouTube is used as a medium for college students to share and access accounting knowlegde.

The analysis technique used in the study is an interactive data analysis technique. In this study, data analysis was carried out together with the data collection process. According to Sugiyono (2010), activities in qualitative data analysis are carried out interactively and take place continuously to completion. That is, in the data analysis researchers are directly involved in explaining and concluding the data obtained by relating the theory used.

The flow of analysis follows the interactive analysis model as expressed by Miles and Huberman (1984). The technique consists of four stages of activity; they are data collection, reduction, presentation and drawing conclusions from the data. First, data collection. Data collected from interview results were mapped and then analyzed to answer research questions. Second, data reduction. The data obtained in the field reminded quite a lot that later there would be many potential answers. It is important to take anticipatory steps, namely simplifying data that has been presented temporarily, then deepening it again and collecting it in accordance with the research objectives so that the data is more specific. Data that has been reduced will provide a clear picture and facilitate researchers for further data collection. Third, data presentation. The presentation of data to be carried out in this study will be in the form of more narrative. The researcher will tell the facts of the field in detail according to what was studied. The presentation of data in the study was carried out in the form of a brief description. Fourth, drawing conclusions. The data that has been presented will be drawn conclusions in the form of interpretations of the research data. The stage of drawing conclusions contains a decision-making process that refers to 
the answers to the research questions submitted and reveals the answers to those questions.

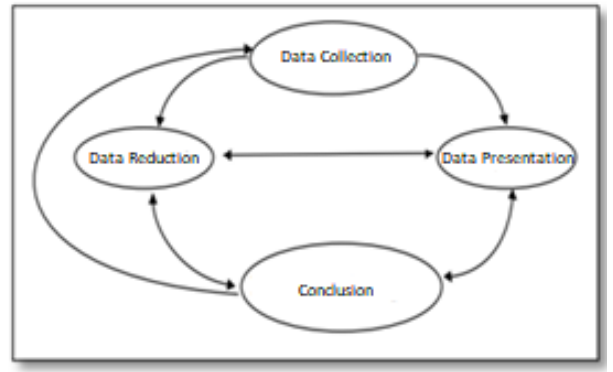

Fig. 1. Interactive Analysis Model

Based on the answers obtained from respondents on the results of the interviews collected, statistical analysis was performed using the formula Dean J. Champion (1990) to manage the results of interview data. In processing the results of interview question data that the researcher presents using questions with the choice of answers given is Yes and No. The results of the answers that have been obtained are calculated using the Champion formula as follows:

$$
\text { Percentage }=\frac{\sum \text { Yes Answer }}{\sum \text { Answer }} \times 100 \%
$$

The results of percentage calculation based on Champion formula are interpreted as follows:

\section{TABLE 1. CHAMPION TABLE}

\begin{tabular}{|c|c|}
\hline Percentage & Remarks \\
\hline $0 \%-25 \%$ & Not Interested \\
\hline $25 \%-50 \%$ & Less Interested \\
\hline $50 \%-75 \%$ & Quite Interested \\
\hline $75 \%-100 \%$ & Very Interested \\
\hline \multicolumn{2}{|c|}{ Source: (Champion, 1990) } \\
\hline
\end{tabular}

\section{IV.RESULT AND EXPLANATORY}

The results showed that interest in sharing and interest in accessing accounting knowledge for college students through YouTube was categorized as quite interested. Result shows that the percentage of interest in sharing accounting knowledge through YouTube is $57 \%$, which is categorized as quite interested. Interest in accessing accounting knowledge through YouTube is $64 \%$ so it is categorized as quite interested. The results of data processing are as follows:

TABLE 2. RESEARCH RESULT

\begin{tabular}{|c|c|c|}
\hline Variabel & Percentage & Remarks \\
\hline $\begin{array}{c}\text { Sharing } \\
\text { Interest }\end{array}$ & $57 \%$ & Quite Interested \\
\hline $\begin{array}{c}\text { Accessing } \\
\text { Interest }\end{array}$ & $64 \%$ & Quite Interested \\
\hline
\end{tabular}

College student interest in Sharing Accounting Knowledge through YouTube

Information obtained from the answers of college students interviewed by researchers shows varied opinions. College students from the Accounting department lack of knowledge about how to make and share videos through YouTube. The other side of college students actually realized that by sharing accounting material they could sharpen their knowledge. College students express by sharing material, can review the material that has been delivered by the lecturer. This makes college students motivated to share accounting knowledge through YouTube.

College students assume that the use of YouTube cannot summarize all accounting material in the class. Material submitted through YouTube content only explains material in general. Explanation through YouTube is not more detailed than the explanation provide by the lecturer. The role of the lecturer cannot be replaced by YouTube. College students express that they are happier with the teaching and learning process in the classroom than through YouTube.

College students express they have a great interest in creating a YouTube account that aims to share accounting material. This material sharing activity can improve the expertise of college students themselves. However, high interest does not make college students active to share videos through YouTube. The problem is the lack of expertise in making and editing videos. The lack of ideas that can be presented into video content is also an obstacle. These things cause low of self-confidence to share accounting material through YouTube.

All information revealed that college students were quite interested in distributing accounting knowledge through YouTube. Realizing how much benefits can be obtained, encourages college students to share accounting knowledge. The lack of ability to make videos is a factor that decreases the interest in sharing accounting knowledge through YouTube.

\section{College student interest in Accessing Accounting Knowledge through YouTube}

The interest of college students to access accounting knowledge through YouTube has different levels. Things that distinguish the level of interest of college students are influenced by their needs. College student needs are influenced by several factors as well.

College students express their knowledge and insight to be broader through the material presented through YouTube videos. Learning becomes easier to understand through animated videos presented by YouTube media. The material through YouTube videos is usually more concise and dense, but not explained in detail given the limited duration of videos that can be uploaded.

The explanation of accounting material obtained through YouTube does not exceed the explanation can be delivered by the lecturer. Not all questions about accounting knowledge can be answered by YouTube. College students cannot receive answers directly when they want to ask questions through YouTube media. The role of the lecturer is very important to answer questions from these college students.

Using YouTube to access accounting knowledge can make the time needed to study accounting material efficient. Searching for material through YouTube also does not fully shorten search time. Some material may not be found on YouTube. The material presented also does not directly refer to the knowledge needed. This requires college students needing more time to find the accounting material needed. 
Watching material in the form of YouTube animated videos makes learning that is boring at first becomes more fun. College students claim that the studies become more interesting if delivered in the form of animated videos. They feel excited when they start the lesson by watching video accounting material through YouTube.

The video presented accounting material on YouTube makes it easier for college students to get the Accounting information. The material presented is explained in a way that is easily understood by the audience. The material through YouTube videos usually explains the material in general, so that the material is not delivered in detail and in full.

The accessible YouTube feature makes college students very interested in creating a YouTube account that aims to access and study accounting knowledge. College students claim they are often access YouTube content in their spare time. The limitation of internet quota is one of the considerations. College students prefer to access YouTube when there is a WiFi network available.

Watching video about accounting material through YouTube for most college students is more interesting than listening to lecturers' explanations. Some of the college students are increasingly proactive in seeking Accounting knowledge through YouTube content. Some are more like searching for knowledge through books. Most college students say they prefer to access material through Google.

College student curiosity increases by accessing accounting material through videos that have been presented through YouTube. Youtube currently has very broad and many content. It's just that the problem is the lack of question space features on YouTube media. This obstacle is the biggest trigger for college students to study and ask directly to lecturers in the class.

Overall information found from the results of the study proves that college students are quite interested in accessing accounting knowledge through YouTube. The material presented on YouTube makes it easy for college students to find the information needed. Facilities and infrastructure become deficiencies that reduce interest in accessing.

\section{CONCLUSION AND RECOMMENDATION}

Based on the research that has been done, it can be concluded:

1. College students are quite interested to share accounting knowledge through YouTube.

2. College students are quite interested to access accounting knowledge through YouTube.

Based on the results of the research that has been done, the researcher has three suggestions as below:

1. Future research is expected to use a broader scope of informants; the scope of the informants in question can be in the form of cities, provinces or countries. The aim is to get more accurate results related to sharing interest and interest in accessing accounting knowledge via YouTube.
2. Second, lecturers can use YouTube as a learning media. The aim is so that learning can be done wherever and whenever as needed.

3. Third, college students need to improve their knowledge related to technology. The aim is for college students ready to face the 4.0 industrial revolution.

\section{REFERENCES}

[1] Almobarraz, A. (2018). Utilization of YouTube as an Information Resource to Support University Courses. The Electronic Library, 7181.

[2] Ayuwuragil, K. (2018, Mei 9). Penonton Youtube, Saingi Jumlah Netizen yang Tonton Televisi. Diambil kembali dari CNN Indonesia:

[3] https://www.cnnindonesia.com/teknologi/20180509180435-185297003/penonton-youtube-saingi-jumlah-netizen-yang-tonton-televisi

[4] Bandura, A. (1977). Social Learning Theory. Englewood Cliffs, NJ: Prentice Hall.

[5] Berliner, \& Gage. (1984). Educational Psychology Third Edition. USA: Houghton Mifflin Company.

[6] Blumer, H., \& Katz, E. (1974). The Use of Mass Communication:Current Prespectives on Gratification.

[7] Briggs, L. J. (1977). Instructional Design. New Jersey : Englewood Cliff: Educational Technology Publications Inc.

[8] Champion, D. J. (1990). Basic Statistic For Social Research,3th edition. New York: Ronald Press Publication, John Wiley and Sons.

[9] Chan, J. (2011). Cara Menulis Daftar Pustaka Yang Benar (2nd ed.). Batam: Bumi Nusantara.

[10] Creswell, J. W. (1998). Qualitative Inquiry And Research Design Among Five Traditions. London: SAGE Publications.

[11] Djaali. (2007). Psikologi Pendidikan. Jakarta: Bumi Aksara.

[12] Herdiansyah, H. (2015). Metodologi Penelitian Kualitatif untuk Ilmu Psikologi. Jakarta: Salemba Humanika.

[13] IAI, I. A. (2009). PSAK No.2 Tentang Laporan Arus Kas. Jakarta: Dewan Standar Akuntansi Keuangan.

[14] McLuhan, M. (1962). The Gutenberg Galaxy: The Making of Typographic Man.

[15] Miles, M. B., \& Huberman, A. M. (1984). Qualitative Data Analysis A Sourcebook of New Methods. Beverly Hills: Sage Publications.

[16] Notoatmodjo, S. (2010). Metodologi Penelitian Kesehatan. Jakarta: Rineka Cipta.

[17] Nurkhin, A., \& Fachrurrozie. (2018). Pemanfaatan Media Sosial Untuk Pembelajaran Akuntansi di Perguruan Tinggi; Studi Empiris di Universitas Negeri Semarang. Seminar Nasional Pendidikan 2018, 110.

[18] Pemerintah Indonesia. (2016, Agustus). Undang-Undang Republik Indonesia Nomor 20 Tahun 2003 Tentang Sistem Pendidikan Nasional. Retrieved from https://kelembagaan.ristekdikti.go.id/wpcontent/uploads/2016/08/UU_no_20_th_2003.pdf

[19] Schramm, W. (1977). Big Media Litle Media. London: Sage PublicBaverly Hills.

[20] Sugiyono. (2017). Metode Penelitian Kuantitatif, Kualitatif, dan $R \& D$. Bandung: Alfabeta.

[21] Sukmadinata, N. S. (2011). Metode Penelitian Pendidikan. Bandung: Remaja Rosdakarya.

[22] Sundari, Z. A. (2019, February 20). Lampaui 10 Juta Subscribers, Atta Halilintar dan Ria Ricis Terima Diamond Play Button. Retrieved from Liputan6: https://www.liputan6.com/showbiz/read/3899959/lampaui-10-jutasubscribers-atta-halilintar-dan-ria-ricis-terima-diamond-play-button

[23] Syakur, A. S. (2015). Intermediate Accounting. Jakarta: AV Publisher.

[24] Yin, R. K. (1994). Case Study Research. Thousand Oaks, London, New Delhi: SAGE Publications. 